This is an Accepted Manuscript of a book chapter published by Routledge in T Kotkas and K Veitch (eds.) Social Rights and the Welfare State: Origins and Transformations on $13^{\text {th }}$ January 2017, available online: https://www.routledge.com/Social-Rights-in-the-Welfare-State-Origins-and-Transformations/KotkasVeitch/p/book/9781138693944

\title{
Unemployment and the Obligatory Dimension of Social Rights
}

Kenneth Veitch

\section{Introduction}

This chapter's objective is to highlight, and think through, the role of obligation in comprehending social rights in the context of the changing nature of the welfare state. There are two reasons for this focus. The first concerns the 'social' dimension of social rights. References to social rights often assume one of two meanings. On the one hand, the 'social' denotes a series of fundamental goods that human beings need access to in order to live: a home, health care, an education, and security of income, for example. Collectively, those goods enable the construction of a social existence. On the other hand, the 'social' of social rights gains its meaning via a comparison of social rights with civil and political rights. In contrast to the latter types of rights - which are often characterised as negative forms of rights, encapsulating a right of freedom from state interference - social rights are identified as pointing to claims against the state; they demand state intervention in order to promote positive exercises of freedom. Moreover, it is often argued that social rights precede the possibility of the meaningful exercise of civil and political 
rights. What use are the latter forms of rights, it is suggested, if, for example, one lacks a basic education? In this second sense, then, the 'social' of social rights finds its meaning by its location within a classificatory model of rights - specifically that proposed by T H Marshall in his essay 'Citizenship and Social Class' (Marshall 1992).

This chapter's focus on obligation advances a different kind of engagement with the 'social' dimension of social rights by shifting the focus towards the form of social relations that might be thought to underpin social rights at different stages in their history. To put it another way, an exploration of the types of obligations, or duties, of citizenship accompanying social rights has the potential to reveal the prevailing principles or political philosophy that guides social rights.

The second reason for this chapter's focus on obligation is to draw attention to the fact that social rights are not necessarily given - provisions that appear in, and can simply be read off, international covenants or countries' constitutions; rather, social rights are fostered or developed - they emerge as the end point of a process that, it is argued here, must be investigated if we are to understand their nature and meaning. Part of that process is the realisation that (social) rights are structured by obligations; that there is a real sense in which obligations precede (social) rights. If this is so, then it is necessary to explore the precise nature of the types of obligation that structure social rights. In the context of the welfare state, this leads to a concern with the duties of citizenship, and especially with understanding their nature and how, and why, that nature might have shifted over time. What, for instance, are the political, economic, and social factors and exigencies that shape the obligations or duties of citizenship in the context of welfare? To what ends are those obligations directed? These are the kinds of questions that animate this chapter's analysis. In summary, the claim made here is that social rights can be understood fully only if the obligations that structure them are the subject of detailed analysis. 
As a comprehensive treatment of how those themes play out across the various fields of welfare is impossible within one chapter, I have chosen to contextualise the discussion by reference to unemployment policy in Britain. The first section focuses upon Sir William Beveridge's 1942 Report Social Insurance and Allied Services - considered to be the founding document of the post-WWII British welfare state - and Marshall's seminal essay, mentioned above. In relation to the Report, this section considers, inter alia, what Beveridge meant by 'right'; the nature of the duties he envisaged; and what kinds of principles underpinned his recommendation of the creation of a compulsory form of social insurance. Insofar as Marshall's essay is concerned, the discussion will look at his notion of social citizenship, and particularly at the nature of the rights and duties this entailed. The chapter then proceeds to an analysis of some recent thinking on the contemporary nature of social rights - including that of 'third way' proponents and their critics. Of course, the discourse of 'rights and responsibilities' has been central to 'third way' ideas about how to reform the welfare state and, practically, to the formulation of social policies devised by politicians and leaders subscribing to this form of thinking. But rather than simply rehearsing this well-trodden terrain, the main aim of the chapter's second section is to identify a correlation between some of the key themes and principles in Beveridge's Report and those emphasised by advocates of the 'third way'. After illustrating how those themes have influenced contemporary academic analysis of social rights and their underlying form of social relations, it is argued that a more convincing diagnosis of these highlights the need to adapt to the exigencies of contemporary capitalism and the labour market. Thus, key themes and objectives of contemporary social policy - including the development of human capital, the fostering of entrepreneurial activity, and the focus on individual responsibility - align with the needs and exigencies of today's labour market and markets generally, rather than being driven by a logic of protection against the vicissitudes of capitalism. The chapter's third section looks at contemporary British unemployment policy and, specifically, 
workfare, together with a Supreme Court case in which the claimants challenged the legality of two workfare schemes. The analysis in this section charts the shifting contours of social rights and, importantly, their underlying obligations by juxtaposing workfare with the earlier analysis of Beveridge's Report and Marshall's essay. The overriding argument is that, while there may be overlapping themes and principles between the two eras, the differences are crucial and point to very different notions of obligation and visions of the social.

\section{Beveridge and Marshall}

Sir William Beveridge's Report on Social Insurance and Allied Services, published in 1942, is generally considered to be the constitutive document of the British welfare state. The Report can be viewed as having had two overriding objectives. First, and famously, its aim was to abolish what Beveridge termed Want. This referred to a phenomenon experienced by many individuals and families in British cities prior to the outbreak of WWII - namely, the lack of means necessary for subsistence. This was predominantly due to unemployment ('interruption or loss of earning power'), and Beveridge's Report was largely concerned with devising a suitable way by which to tackle Want. The main mechanism proposed was a scheme of compulsory social insurance. ${ }^{1}$ Under this scheme, individuals would make weekly contributions from their earnings to a State insurance fund and be able to draw benefits from it, up to subsistence level and irrespective of means, when, inter alia, unemployed, ill, in the event of becoming disabled, and upon retirement. In other words, access to the fund would be dependent on having contributed to it. The Report's second objective was to streamline and simplify the existing patchwork of social insurance schemes, the different principles upon which they operated, and their administration. 
The existing setup had become too costly to run and also too complex to navigate for those it was meant to serve.

For present purposes, two important questions arise: first, do we encounter a discourse of social rights within the Beveridge Report; and, secondly, what type of political philosophy underlies the Report's proposals? Insofar as the former is concerned, while the discourse of "social rights" per se is absent from the Report, Beveridge does occasionally speak of 'right'. This, however, only applies in the context of one's right to draw from the social insurance fund to which one has contributed. As well as unemployment benefit, this can be seen in relation to the Report's proposal to move from a system of pensions based on need to one in which 'pensions are paid as of right to all citizens in virtue of contribution.' (Beveridge 1942, para. 16) Under the Report, then, 'right' is inextricably linked to having made a contribution; social rights, if we call them such for the moment, are predominantly the rights or entitlements of individuals who have been, but are now no longer, employed. Social rights are the individual rights of contributors to monetary benefits in hard times - benefits that replace missing income in order to prevent Want and the symptoms associated with this. As such, the Report's proposals for a compulsory social insurance scheme are equated to individual contribution 'rather than free allowances from the State'.

Secondly, what can be said of the political philosophy underpinning the proposed reforms and the right to benefits associated with compulsory social insurance? Harris's comment that the Report 'was a complex mixture of traditional Edwardian liberalism and wartime collectivism' provides an accurate and useful starting point (Harris 2004, p. 290). On the one hand, Beveridge's desire to abolish Want was very much bound up with the ongoing war at the time and, in particular, with drawing on the perceived collectivism across the nation as the basis for the proposals for a new social security system. Although 
not stated as a guiding principle of the Report's recommendations, it is clear from the following quotation that the notion of solidarity played a role in grounding the new system:

The proposals of the Report mark another step forward to the development of State insurance as a new type of human institution, differing both from the former methods of preventing or alleviating distress and from voluntary insurance. The term "social insurance" to describe this institution implies both that it is compulsory and that men stand together with their fellows. The term implies a pooling of risks except so far as separation of risks serves a social purpose (Beveridge 1942, para. 26).

For Beveridge, compulsory social insurance marked a shift from earlier forms of State insurance in Britain. Those earlier forms operated on the principle underlying voluntary insurance - namely, that of adjusting premiums to particular risks, rather than the pooling of risks, which was to be the underlying principle of the Report's proposed scheme. Solidarity can also be detected, inter alia, in the scheme's universal nature, which was to extend beyond those currently covered - manual workers - to encompass all citizens irrespective of their level of income; in its provision of a flat rate of subsistence benefit to all those insured and the existence of a flat rate of contribution; and in the principle of sharing the cost of social security amongst the insured individual, his or her employer, and the State. Thus, social security was to be achieved through cooperation between the State and the individual - what Grady identifies as 'a relationship characterised by joint responsibility' (Grady 2010, p. 164).

On the other hand, a liberal form of social relations can be detected within the Report. Building on the principle that State social security should be granted on the basis of citizens' service and contribution, by limiting benefits to subsistence levels the Report sought to encourage individuals to take steps to 
enhance their social security through voluntary action. State security, it was said, 'should not stifle incentive, opportunity, responsibility'. Part of the purpose of the new social insurance system was therefore to promote individual freedom and responsibility for one's own security; State security was not only designed to abolish Want - although, crucially, this was its main aim - but also to incentivise individuals by providing them with just enough, and no more, for them to want, and seek, to achieve a heightened level of social security through the exercise of their own initiative. Those themes resonate with other liberal principles running throughout the Report and which can clearly be seen from the following quotation that appears under the heading 'Planning for Peace in War':

There are some to whom pursuit of security appears to be a wrong aim. They think of security as something inconsistent with initiative, adventure, personal responsibility. That is not a just view of social security as planned in this Report. The plan is not one for giving to everybody something for nothing and without trouble, or something that will free the recipients for ever thereafter from personal responsibilities. The plan is one to secure income for subsistence on condition of service and contribution and in order to make and keep men fit for service. It cannot be got without thought and effort. It can be carried through only by a concentrated determination of the British democracy to free itself once for all of the scandal of physical want for which there is no economic or moral justification (Beveridge 1942, para. 455).

To the extent that one can conceptualise Beveridge's system of social insurance in a discourse of social rights, it is suggested that what underpins the right to pecuniary benefits is an idea of social relations based upon duty, individual responsibility, effort, and reciprocity. The key duty is to engage in paid work, as it is this that produces the contributions that are the condition of access to the benefits of the social insurance fund. While solidarity (in the sense of a pooling of risks) is, as we saw above, an important 
feature of the proposed scheme, as Harris notes Beveridge's aim was 'not to redistribute income between classes, but 'between times of earning and not earning, and between times of heavy family responsibilities and of light or no family responsibilities'.' (Harris 2004, p. 290, quoting the Report). Thus, the type of solidarity involved in the context of social insurance here was not one designed to promote an equitable or fair allocation of resources or wealth across the various classes in society. The centrality of duty can also be found in the conditionality attaching to the receipt of different types of benefit. Thus, while unemployment benefit will continue throughout the duration of the period of unemployment, it will usually be conditional upon attendance at a work or training centre after a certain amount of time. Similarly, the ongoing receipt of disability benefit would be conditional upon the 'imposition of special behaviour conditions'.

In summary, the 'social right' to access the funds of the new social insurance system posited both a collective and liberal vision of social relations. Regarding the former, social insurance involved the duty to participate in paid work and, through that, to contribute to a common fund that contributors and their families could access in hard times. And underpinning this obligation was the vision of a bond amongst one's 'fellows' - a bond that, crucially, had as its objective a protective and compassionate function, namely the removal 'of the scandal of physical want for which there is no economic or moral justification'. Insofar as the liberal sense of social relations is concerned, through the provision of basic subsistence, the Report emphasised the importance of incentive, individual initiative, individual responsibility, and voluntary action in its exhortation to individuals to enhance their, and their families', social security. And in addition to identifying the important role to be played by the State in tackling physical want and the other evils of squalor, disease, ignorance, and idleness, security against these was to be 'combined with freedom and enterprise and responsibility of the individual for his own life.' (Beveridge 1942, para. 456) Thus, the social protection offered was accompanied by the State's interest 
in shaping a particular type of subjectivity - one characterised by individual responsibility and enterprise.

In 1949, seven years after the publication of Beveridge's Report, T H Marshall delivered The Marshall Lectures at Cambridge University (Marshall 1992). Unlike Beveridge, Marshall explicitly deployed the discourse of social rights in his now famous analysis of citizenship and rights (specifically, civil, political, and social rights). It is not the intention here to rehearse this analysis, but simply to identify a couple of pertinent points from Marshall's reflections on the rights he associates with the social element of citizenship. The first relates to his definition of social citizenship, which is as follows:

By the social element I mean the whole range from the right to a modicum of economic welfare and security to the right to share to the full in the social heritage and to live the life of a civilised being according to the standards prevailing in the society. The institutions most closely connected with it are the educational system and the social services (Marshall 1992, p. 8).

Marshall's concept of social citizenship, and therefore of social rights, is wide-ranging. While clearly incorporating what the Beveridge Report called a right to benefits at subsistence level (Marshall's 'right to a modicum of economic welfare and security'), it extends far beyond this. Or, perhaps better, it describes in the discourse of rights the latent aspirations to which Beveridge's proposals for the abolition of Want were presumably designed to give rise. Of particular note for this essay, in this regard, is Marshall's idea that social rights include the right 'to live the life of a civilised being according to the standards prevailing in the society'. For Marshall, this represented his idea of citizenship - namely the claim 'to be accepted as full members of the society, that is, as citizens'. There is, he argued, 'a kind of basic human equality associated with the concept of full membership of a community.' Later, he 
explains that social rights 'imply an absolute right to a certain standard of civilisation' and suggests that the types of changes proposed by Beveridge - including the system of compulsory social insurance enhance the prospect of a civilised life for everyone in society and reduce the incidence of risk and insecurity for citizens.

The second observation to be made of Marshall's analysis of social citizenship and social rights is the importance he places, towards the end of his lecture, on the corresponding duties of citizenship and the need to discharge them. The more precise of these - such as the duty to pay insurance contributions replicates the types of duty Beveridge demanded of citizens in his Report. But Marshall also mentions the need for the discharge of less specific duties. Thus, the right to a certain standard of civilisation is, he says, conditional on discharging 'the general duties of citizenship'. While '[t]hese do not require a man to sacrifice his individual liberty or to submit without question to every demand made by government ... they do require that his acts should be inspired by a lively sense of responsibility towards the welfare of the community.' (Marshall 1992, p. 41) It is 'the general obligation to live the life of a good citizen' that constitutes the substance of those wider duties, and to the extent that Marshall lends a more particular meaning to such duties, he says the duty to work is of key importance in this respect. This duty of social citizenship does not merely envisage individuals finding a job and retaining it; rather, the essence of the duty is 'to put one's heart into one's job and work hard'. And it is by engaging in this activity equivalent to a kind of service to the community and the nation (although Marshall acknowledges that there are problems with this) - that citizens will discharge their general duty and responsibility towards the welfare of the community.

What emerges from the foregoing analysis is how, for Beveridge and Marshall, social rights are structured by obligations or duties. The right to access basic levels of money or, more expansively, to 
live the life of a civilised being are conditional upon discharging a number of obligations - including, significantly, undertaking paid work. And those obligations, in their readings, are underpinned by a form of social relations based upon a sense of solidarity that had as its object the eradication of Want and the right to live the life of a civilised being. Simultaneously, one detects the importance of a liberal form of social relations that stresses principles of individual effort, self-responsibility, and enterprise. Bearing the foregoing analysis in mind, let us now turn to consider some of the principles that ground contemporary understandings of social rights and social policy.

\section{Social Rights and Responsibilities: 'Third Way' Thinking and Neoliberalism}

The promotion of social justice was sometimes confused with the imposition of equality of outcome. The result was a neglect of the importance of rewarding effort and responsibility, and the association of social democracy with conformity and mediocrity, rather than the celebration of creativity, diversity and excellence.

Too often rights were elevated above responsibilities, but the responsibility of the individual to his or her family, neighbourhood and society cannot be offloaded on to the state. If the concept of mutual obligation is forgotten, this results in a decline in community spirit, lack of responsibility towards neighbours, rising crime and vandalism, and a legal system that cannot cope.

Modern social democrats want to transform the safety net of entitlements into a springboard to personal responsibility. 
(Blair and Schroeder 1998, cited in Dardot and Laval 2013)

What is remarkable about those statements, which appear in Tony Blair and Gerhard Schroeder's Europe: The Third Way/Die Neue Mitte, is the degree to which they reflect many of the principles and themes underlying the Beveridge Report and Marshall's discussion of social citizenship and social rights. It is remarkable in the sense that Beveridge's Report is often held out as exemplary of a golden era of the welfare state founded on principles that can be contrasted with those underlying 'third way' social policies. As I will demonstrate later, this is not to say that there are no important - indeed, fundamental - differences between the two or that Beveridge and Marshall would have approved of today's social policies; nevertheless, there are common themes, including the following: the need for a balance to be struck between rights and responsibilities; the importance of individual responsibility; the enabling state (basic state benefits should facilitate mechanisms of self-help); and the emphasis on individual initiative and creativity. The concerns and issues that led to Blair and Schroeder's statements above are many and cannot be discussed adequately in this chapter. In what follows, I will, first, briefly outline one argument concerning the impact of this philosophy upon the contemporary nature of social rights. Secondly, I will suggest that this philosophy is more adequately explained as deriving from neoliberalism and a neoliberal rationality. Finally, with reference to current unemployment policy in the UK and a recent legal case, I will analyse how obligations or duties structure social rights today and relate this back to the earlier discussion of Beveridge and Marshall.

French academic Pierre Rosanvallon has argued that, owing to the decline of traditional principles of social solidarity and the emergence of long-term unemployment and exclusion as core contemporary problems, the traditional form of social rights within the welfare state - that is, rights to compensatory benefits - is no longer fit for purpose (Rosanvallon 2000, p. 88). In light of those problems, he proposes 
reconceptualising contemporary social rights as rights to 'social usefulness' - that is, as means of ensuring the re-inclusion of individuals in society such that they do not simply have a right to live (the right Rosanvallon equates to the social right to benefits of the classical welfare state) but 'a right to live in society'. Social rights are therefore bound up with social participation and the realisation of citizenship. They have as their objective the construction of a new type of social bond - the reestablishment of the social relation for those currently excluded - and the right to this bond. Beyond the right to pecuniary subsistence, today's social rights incorporate 'a moral imperative' too - the right to be a socially useful member of society. Rosanvallon equates the former right to passivity, and the latter to activity and the notion of active citizenship. In his view, this type of citizenship, and its corresponding right to social usefulness, form the basis of a new type of contemporary solidarity. It results in the excluded (re-)engaging or participating in society and converts the welfare recipients of the traditional system of collective insurance into citizens.

This vision of social rights in the 'inclusive society' places individuals, rather than groups or classes, at its core and envisages an important role for obligation. Thus, if social rights are to be about re-inclusion in society, not only do we need to focus on the individual and his or her particular needs, circumstances and behaviour (including its constant supervision); individuals must become active, responsible citizens making and discharging a series of commitments too. In this context, the notion of contract becomes an important technique in this reformulation of social rights in that 'social rights are reinterpreted as a contract articulating rights and obligations.' Rosanvallon argues that these contracts, with their mutual set of responsibilities (on the individual and the state), point to a notion of the individual as 'an autonomous, responsible person, capable of making commitments and honouring them.' And it is through the recognition of this type of person and the obligations he or she commits to undertake that the individual is re-socialised and, as a result, society is constructed and reaffirmed. Individual 
responsibility is therefore an important theme of this philosophy; by accepting this responsibility, individuals are deemed to be empowered as they take ownership of, for example, their unemployment by actively adopting measures to (re-)integrate themselves into the labour market and thus society. Rosanvallon's notion of social rights posits 'a contractual individualism combining respect for the individual with the reconstruction of the social bond.' (Rosanvallon 2000, p. 92)

Rosanvallon's work presents an interesting rethinking of social rights and the form that solidarity might take in the context of contemporary welfare and social policy. Its underlying philosophy clearly maps on to the type of 'third way' thinking of Blair and Schroeder set out above, and resonates with some of the themes appearing in the Beveridge Report and Marshall's analysis of social rights and social citizenship. The focus on individual responsibility, reciprocity, and, what might be taken to be especially relevant here, Marshall's idea of social citizenship as a right not merely to a modicum of economic welfare but extending to include a right to live the life of a civilised being - all feature prominently in Rosanvallon's analysis. It is suggested, however, that his is a limited and sanguine account of the transformations in the welfare state and social rights that have spread across a number of Western countries in recent decades and of the type of rationality that has underpinned them. If we are to understand the structure of social rights today - especially the kinds of obligations that ground them - it is necessary to undertake a more critical and concrete analysis.

It could be argued that the problem 'third way' thinkers and politicians had with Beveridge's and Marshall's reflections lay not so much in their underlying principles but in the fact that the strong link they envisaged between rights and duties failed to materialise in practice. As is clear from the quotations above, the allegation was that, while the welfare state that developed after WWII ensured social rights by providing access to a variety of protective measures, it failed to demand anything of 
welfare recipients in return. Along with highlighting the issue of the increasing costs of welfare as a reason for rising scepticism about the welfare state, Pierre Dardot and Christian Laval note that critiques of the welfare state beginning in the 1980 s began to represent this as a vehicle of demoralisation (Dardot and Laval 2013). The bureaucratic welfare state, the argument went, and still goes today, 'destroys the virtues of civil society - honesty, the sense of a job well done, personal effort, civility and patriotism.' (Dardot and Laval 2013, p. 164) The welfare state was viewed as being too generous and, because of that, accused of creating welfare dependency and inertia on the part of welfare recipients. The incentive to, and passion for, work that Marshall identified as one of the general duties of citizenship, was nullified and welfare beneficiaries, for that reason amongst others, came to be represented as morally irresponsible. In other words, state benefits may have provided the protection against the physical want, insecurity and risk that Beveridge identified as dangers; but that desired outcome had, it was argued, dulled the very initiative and individual responsibility that Beveridge believed his system would produce. Moreover, the 'demoralisation' thesis could not be understood simply as a moral denunciation of welfare recipients or in terms of the symbolic effects this produced; additionally, and crucially, it concerned the erosion of the types of principles upon which the prevailing economic system depended. As Dardot and Laval conclude with regard to such critiques: 'In a word, social protection was destructive of the values without which capitalism could no longer function.' (Dardot and Laval 2013, p. 165; reference omitted)

Nowhere has this critique of the welfare state been more influential and pronounced than in the creation of 'welfare to work' programmes. Such programmes can be viewed as having a dual function: first, by seeking to return the unemployed to work, they aim to reduce costs and promote flexible labour markets, thereby enabling states to remain economically competitive in an increasingly global marketplace (Jessop 2002); secondly, through onerous sanctions for failing to participate in such 
programmes, they discipline the unemployed, thereby making them assume the individual responsibility that the welfare state had allegedly destroyed through its inculcation of passivity. 'Jobseekers' were to become enterprises in themselves - entrepreneurs who take responsibility for their own development, and work on cultivating their human capital with a view to returning to the labour market as soon as possible. Social rights as such - here, in the form of the jobseeker's allowance (JSA) - did not disappear, but access to them was now strictly conditional upon satisfying various commitments and obligations set out in the type of contract mentioned by Rosanvallon. For authors such as Dardot and Laval though, the essence of a social policy like workfare cannot be grasped within the framework of Rosanvallon's analysis - as a qualitative shift in the nature of social rights and solidarity that promoted the integration of the excluded into society, thereby reaffirming social citizenship and social bonds. Rather, for them, it represented a rupture in the nature of society, the social bond, the individual, and the governing rationality. For the architects of New Labour and the third way, social justice and the social bond were to be re-structured around competition, individual responsibility, equality of opportunity, and the fostering of human capital, rather than around 'greater solidarity and objectives of real equality'. Homo economicus was no longer merely the creature of the market, but of social policy too; and the state's objective was no longer driven by a principle of protection, but, through 'social investment' in individuals, by the desire to ensure their adaptation to markets and a market-based society. As Jacques Donzelot summarises: '[S]ocial policy is no longer a means for countering the economic, but a means for sustaining the logic of competition.' (Donzelot 2008, p. 124) In short, the social policy of the third way had been defined by what Dardot and Laval call a neoliberal rationality and form of social relations, the key feature of which 'is the generalization of competition as a behavioural norm and of the enterprise as a model of subjectivation.' (Dardot and Laval 2013, p. 4) By actively embedding this norm and model both materially and symbolically, the state establishes the conditions necessary for a market-based society. 
Let us now turn to consider the implications of such developments for our contemporary understanding of social rights and obligation by considering more closely the social policy of workfare as it operates in Britain and relating this back to the rights and obligations identified by Beveridge and Marshall.

\section{Workfare in Britain: Transforming Social Rights and Obligations}

As we saw earlier, the right to access monetary benefits under Beveridge's social insurance system was structured by an obligation to undertake paid work. It was by virtue of the contribution made from one's salary each week that one was entitled to access State benefits. The importance of work for Beveridge, however, extended beyond the need to have already been employed as a condition of accessing benefits. As the Report noted: 'The correlative of the State's undertaking to ensure adequate benefit for unavoidable interruption of earnings, however long, is enforcement of the citizen's obligation to seek and accept all reasonable opportunities of work.' (Beveridge 1942, para. 130) Moreover, it was proposed that benefits for the long-term unemployed would normally be conditional on attending a work or training centre. This early form of active citizenship, however, was not novel - the requirement that the unemployed should bear and discharge obligations in return for receiving pecuniary support from the state having existed for some time already. ${ }^{2}$ But what can be said of this obligation today? The contemporary manifestation of this requirement - the welfare-to-work or workfare scheme - is both more onerous in the demands it makes of the unemployed (not only being available for, and actively seeking, work; but in some cases, actually working) (Freedland et al 2007, p. 196) and more punitive in the sanctions flowing from a failure to discharge those obligations. ${ }^{3}$ In what follows, it will be argued that, despite the similarity in certain themes and principles to be found in Beveridge's Report and 'third 
way' thinking - including reciprocity and individual responsibility - the nature of the obligations demanded of the unemployed in return for JSA is not in keeping with other core principles underpinning Beveridge's and Marshall's visions for the welfare system. Thus, while the duty to work remains alive and well in the sphere of unemployment policy today, the nature of this duty sheds a different light on the purpose and structure of contemporary social rights. Consideration of a legal case in England will help to illuminate this argument.

In R. (on the application of Reilly and Wilson) $v$. The Secretary of State for Work and Pensions (hereinafter referred to as Reilly \& Wilson), the claimants - Caitlin Reilly and Jamieson Wilson challenged the validity of the Jobseeker's Allowance (Employment and Enterprise) Regulations 2011 ('the Regulations') and two workfare schemes or programmes known as 'the sbwa scheme' (the sectorbased work academy scheme) and 'the CAP' (the Community Action Programme). The sbwa scheme, which was the object of Reilly's challenge, is a voluntary scheme designed to help those able to perform work-related activity and who do not have any serious barriers to finding work to obtain short-term work-focused training and work experience linked to a genuine job vacancy. Her basic contention was that she had been incorrectly, and therefore unlawfully, required to participate in the sbwa scheme on pain of possibly losing her JSA entitlement or having her payments reduced. As she could not afford to lose her only source of income, she felt she had no alternative but to participate. Moreover, rather than simply the one week's "training" she was told she would undergo, she ended up having to work for nothing for two weeks ( 5 hours a day, 5 days a week) for a budget retail outlet called Poundland. The CAP, the object of Wilson's claim, is a Programme for the long-term unemployed, which individuals, selected by 'random allocation', must attend if they wish to continue receiving JSA. It involves undertaking up to six months' unpaid work experience for up to 30 hours per week and 'weekly job 
search support requirements'. Wilson refused to participate in the CAP, claiming it, and his required participation, were unlawful. ${ }^{4}$

The claimants' actions, which went all the way to the Supreme Court, were successful because the Regulations were found to have failed to describe the relevant schemes or the circumstances in which individuals can be compelled to participate in them (as was required by the enabling Act (s.17A, Jobseekers Act 1995)). As a result, the Regulations were declared unlawful and quashed. For present purposes, the interest of the case revolves around the claimants' identification of what they argued was the compulsory nature of the relevant law. This was most obvious in their final ground of challenge namely, that the schemes violated Article 4 of the European Convention on Human Rights as they required the performance of "forced or compulsory labour" (Article 4(2)). In light of the nature of the CAP (described above) Wilson argued that it imposed 'very onerous obligations on individuals', requiring them to work for nothing if they wished to continue receiving JSA. For those with no savings of their own, the threat of withdrawal of the means to live effectively amounted to a compulsion to participate in the scheme. Wilson objected to working for free, particularly for such a long time and thought this was unfair. Reilly argued that the violation of Article 4 lay in not being given 'the option to participate in a scheme that involved unpaid work for a private company and that the work she undertook was under the threat of a penalty.' (Reilly \& Wilson [2012] EWHC 2292 (Admin), para. 171, per Foskett J)

None of the courts that heard the case found that the schemes violated Article 4. Agreeing with Foskett $J$ in the High Court, the Supreme Court stressed that the historical roots of Article 4 lay in the need to prevent exploitation of labour in the colonies. While forced labour could take different forms, its underlying essence was exploitation, and a conditional state benefit such as JSA 'comes nowhere close to the type of exploitative conduct at which article 4 is aimed.' (Reilly \& Wilson [2013] UKSC 68, para. 83) 
The article would only be violated if: 1) the work undertaken was compulsory or involuntary, and 2) 'the obligation to work, or its performance, [was] "unjust", "oppressive", "an avoidable hardship", “needlessly distressing" or "somewhat harassing"' (Reilly \& Wilson [2013] UKSC 68, para. 89). In other words, the work or its performance needed to be exploitative. The reason advanced for the Supreme Court's conclusion on this ground of challenge revolved around the inextricable link drawn by the justices between the state benefit and the condition to be met in order to receive this benefit: as JSA is designed for individuals seeking work, the purpose of the benefit - to enable a person to seek work - is furthered by the condition of working or engaging in work-related activity. As such, the condition cannot amount to exploitation. Neither were the schemes compulsory or involuntary as the claimants were free to refuse to participate in them if they so wished. Furthermore, that the work undertaken was unlikely, in fact, to improve an individual's employment prospects was irrelevant in ascertaining whether the imposition of labour as a condition of obtaining JSA amounted to forced labour under Article 4.

What can this case tell us about contemporary social rights in the context of unemployment? And how do these compare to the rights and duties of social citizenship discussed by Beveridge and Marshall? First, if, as we saw earlier, the right envisaged by Beveridge was a right to draw from the social insurance fund to which one had contributed - a right of contributors to monetary benefits during periods of interruption of earnings - as the Supreme Court noted in Reilly \& Wilson, the JSA is an allowance designed for people who seek work, rather than for those who have simply made financial contributions to the fund. In other words, the social right to the monetary benefit cannot be divorced from the obligation actively to seek work and, where demanded, to undertake work as part of the process of trying to secure a paid job in the labour market. Of course, in return for State benefits, Beveridge spoke of the citizen's correlative obligation to seek, and accept, all reasonable opportunities for work. But the work he referred to was paid employment within the labour market - something very different to an 
obligation to undertake the type of unpaid work demanded by the CAP. The nature of the obligation underlying the social right associated with periods of unemployment has therefore shifted decisively in the direction of work - not in the sense of having engaged in paid work and contributed to the social insurance fund (although this is still important ${ }^{5}$ ); but in the sense of actively seeking work, engaging in training activities designed to ready people for employment, and working for nothing while unemployed.

Secondly, the main objective of Beveridge's Report was to tackle the scourge of Want - namely, the absence of the means required for individuals to live. His scheme of social insurance was designed to address the insecurity and risk flowing from this social reality. There are signs that a similar objective does not necessarily underpin the social right synonymous with the current workfare system. For this right - to JSA - is, at least partially, built on the constant threat to remove the means of subsistence. If, for example, jobseekers do not undertake the obligations set out in what is now called their 'claimant commitment', or fail to turn up for an appointment at the job centre, or turn down a job or training course, or do not apply for any jobs they are informed about, the sanctions regime will come into operation, progressively reducing the amount of JSA until, ultimately, it disappears completely. What the claimants in Reilly \& Wilson called 'the "draconian power" to take away the right to what is, in many respects, a subsistence-level payment', demonstrates that the power to produce, rather than to free individuals from, Want lies at the core of contemporary unemployment policy - something that has potentially negative social consequences (see, for example, Great Britain: Scottish Government 2013; Great Britain: House of Commons 2015). The social right associated with the workfare system is structured in such a way as to be inherently insecure - that is, always liable to be taken away. 
Thirdly, while important, our comprehension of social rights in the context of the workfare system remains limited insofar as it is conceptualised solely at the monetary level. Here, we can return to Marshall's broader, non-pecuniary, understandings of social citizenship and social rights - and in particular, to his idea of social citizenship incorporating the right 'to live the life of a civilised being according to the standards prevailing in the society', and to his contention that social rights 'imply an absolute right to a certain standard of civilisation'. To what extent does today's workfare system reflect those definitions of social citizenship and social rights? One might anticipate Reilly's and Wilson's answers to this question being: "very little". This was implicit in their claims that what the obligations they were being asked to discharge amounted to was forced labour and, therefore, exploitation. For them, there was something "unjust", "oppressive", "needlessly distressing", and that amounted to "an avoidable hardship", in being obliged to undertake long periods of unpaid work for organisations, including a private company.

Relatedly, when measured against Marshall's general duties of citizenship that he identified as accompanying social rights, workfare would seem to fare no better. It will be recalled that, for Marshall, those general duties were the flipside of the right to a certain standard of civilisation. But in light of some of the obligations to be undertaken by individuals in return for JSA, it is difficult to comprehend how they would 'be inspired by a lively sense of responsibility towards the welfare of the community' or be willing to assume 'the general obligation to live the life of a good citizen'. More directly, it is also questionable whether Marshall's understanding of the citizen's duty to work holds any relevance in the present context. For not only do the obligations of workfare suggest that the essence of his idea of the duty to work - putting one's heart into one's job and working hard - is unlikely to be assumed and discharged by unemployed individuals like Reilly and Wilson; ${ }^{6}$ achieving what Marshall considered to be the other, easily dischargeable components of this duty (in light of the context of full employment in 
which he was writing) - to find a job and retain it - looks increasingly dubious for many involved in workfare. $^{7}$

Finally, where does the foregoing discussion leave us? Most immediately, it directs us to the possible relevance today of the limits Marshall placed on the need to discharge the 'general duties of citizenship', including the duty to work. For these, he said, 'do not require a man to sacrifice his individual liberty or to submit without question to every demand made by government.' While the courts in Reilly \& Wilson denied the claimants' contention that the workfare schemes amounted to forced labour, it was clear that one of Reilly's and Wilson's core reasons for so arguing was that the threat of removal of JSA effectively denied them the freedom to choose not to undertake unpaid work. In other words, they argued that, in order to continue receiving subsistence level benefits, they had no practical alternative but to submit to the demands made by the government. The possible relevance of Marshall's qualification to the obligation to discharge the general duties of citizenship suggests a tipping point may have been reached in the duties placed upon the unemployed today.

\section{Conclusions}

This last point leads to a few conclusions. First, the nature of the relationship between social rights and obligations in the context of unemployment policy has shifted in recent decades. As noted earlier, Beveridge's idea of a social right involved a right to draw a benefit from a social insurance fund based on the contributions one had made to this through paid work. The obligation upon which this right rests is therefore the obligation to engage in paid work. The benefit was to be set at subsistence level in order to promote individual efforts to develop one's own sources, and heighten one's own level, of security. 
But now it is this - proving one's initiative, enterprise, and creativity, including one's susceptibility to undertaking unpaid work - rather than engagement in paid work, that has become the obligation that grounds the right to JSA. Crucially, Beveridge's objective in recommending a system of compulsory social insurance was to free the population from Want. Today's workfare system represents a shift in the settlement between social rights and obligations in the sense that access to JSA is premised on a set of obligations that are, at least to a degree, at odds with the types of obligation associated with Beveridge's social insurance system. Reilly and Wilson illustrates this well in that, rather than access being based on paid work, the allegation was that exploitation in the form of forced labour founds one's right to JSA, and that refusing to be exploited will lead to a sanction that will result in Want and the insecurity and poverty that are its symptoms. Such obligations and outcomes are diametrically opposed to the principles upon which Beveridge's Report rested, including not only freedom from Want but the sense of solidarity implied by the institution of social insurance - namely, that 'men stand together with their fellows'.

Secondly, this suggests that the workfare system is not primarily driven by a protective logic, but, as Dardot and Laval argue in respect of the neoliberal state, by an adaptive one. Indeed, here, one can witness the development of a more fluid relationship between right and obligation. For the right to JSA is not equivalent to a social benefit designed to modify the vagaries, risks, and insecurities endemic in the economic system - the operating logic of the classical welfare state; indeed, quite the opposite. Through the obligations demanded of participants, the right to JSA is inextricably bound up with readying unemployed individuals for what they can expect to encounter in the contemporary flexible and competitive labour market - including temporary, insecure, low-paid, or unpaid work. The UK Government's explanation of the rationale behind the workfare scheme known as Mandatory Work Activity captures this well: 'MWA is intended to help claimants move closer to the labour market, 
enabling them to establish the discipline and habits of working life' (Great Britain: DWP 2015). The workfare system trains and disciplines individuals in order to habitualise them to the reality of contemporary labour, and exposes and reconciles them not necessarily to the old virtues of social security and freedom from Want that structured the classical welfare state, but to the 'virtues' and characteristics around which the neoliberal rationality that guides the current political settlement revolves - including insecurity, risk-taking, and competition. This suggests a deeper sense of obligation at play here, deriving from the idea, inherent in the etymological root of the word, of a bond or being bound. ${ }^{8}$ On the one hand, the jobseeker is trained to be bound to the practices and forms of labour temporary contracts and unpaid internships, for instance - typical of what some authors have termed 'the new capitalism' (Sennett 2006; Boltanski \& Chiapello 2005). On the other hand, he or she is bound subjected even - to a transformation at the level of subjectivity, to become the enterprising, selfresponsible, risk-taker ready to learn new skills in order to be able to adapt to, and compete within, the dynamic contemporary labour market. What is involved here is a shift in the mode of being; as Dardot and Laval note: 'at stake in neo-liberalism is nothing more, or less, than the form of our existence - the way in which we are led to conduct ourselves, to relate to others and to ourselves.' (Dardot and Laval 2013, p. 3; original emphasis) It is at this deep level of the form of 'relat[ion] to others' that workfare is most revealing. For it illustrates that this no longer takes the form of Beveridge's notion of men standing together with their fellows, but of the lone individual working upon his or her self with a view to competing with other, unencumbered individuals engaged in exactly the same activity. This, it is suggested here, captures the underlying sense of Blair and Schroeder's understanding of the desire of modern social democrats 'to transform the safety net of entitlements into a springboard to personal responsibility'. 
Finally, in light of the discussion in this paper, an urgent question presents itself: To what extent is it even relevant to deploy the discourse of 'social rights' as a means of comprehending current unemployment policy in the UK? As we saw earlier, Rosanvallon argued that the old idea of social rights as a right to live associated with access to compensatory benefits needed updating in what he described as an era of long-term unemployment and exclusion. Social rights should, instead, now be conceptualised as a right to live in society - a right to social usefulness. The analysis in this chapter suggests that the type of contractual system he promoted as the means of realising this new form of social right - the workfare system - not only has dubious success in re-intergating the unemployed into society and establishing for them a new social bond; it also has the potential to endanger what he views as the old, out-dated form of social right - the right to live.

\section{Bibliography}

BEVERIDGE, W. (1942) Social Insurance and Allied Services. London: H.M.S.O. (Cm. 6404)

BLAIR, T. and SCHROEDER (1998) Europe: The Third Way/Die Neue Mitte

BOLTANSKI, L. \& CHIAPELLO, E. (2005) The New Spirit of Capitalism. London: Verso.

CARPENTER, M., FREDA, B. and SPEEDEN, S. (eds.) (2007) Beyond the Workfare State: Labour Markets, Equality and Human Rights. Bristol: Policy Press.

DARDOT, P. and LAVAL, C. (2013) The New Way of the World: On Neoliberal Society. London: Verso.

DONZELOT, J. (2008) Michel Foucault and Liberal Intelligence. Economy and Society. 37(1). p.115134. 
FREEDLAND, M. ET AL (2007) Public Employment Services and European Law. Oxford: Oxford University Press.

GRADY, J. (2010) From Beveridge to Turner: Laissez-faire to neoliberalism. Capital \& Class. 34(2). p.163-180.

GREAT BRITAIN: DEPARTMENT FOR WORK AND PENSIONS (DWP). (2014) Evaluation of the Day One Support for Young People Trailblazer. London: Research Report.

GREAT BRITAIN: DEPARTMENT FOR WORK AND PENSIONS (DWP). (2015) Mandatory Work Activity Provider Guidance. London.

GREAT BRITAIN: HOUSE OF COMMMONS. (2015) Benefit Sanctions Policy beyond the Oakley Review. London: The Stationery Office.

GREAT BRITAIN: SCOTTISH GOVERNMENT. (2013) The Potential Impacts of Benefit Sanctions on Individuals and Households. Edinburgh: Welfare Analysis.

GRIGGS, J. and EVANS, M. (2010) Sanctions within Conditional Benefit Systems: A Review of Evidence. Oxford: Joseph Rowntree Foundation.

HARRIS, B. (2004) The Origins of the British Welfare State: Social Welfare in England and Wales, 1800-1945. Basingstoke: Palgrave Macmillan.

JESSOP, B. (2002) The Future of the Capitalist State. Cambridge: Polity. 
MARSHALL, T.H. (1992) Citizenship and Social Class. In MARSHALL, T.H. and BOTTOMORE, T. Citizenship and Social Class. London: Pluto.

NICHOLAS, B. (1962) An Introduction to Roman Law. Oxford: Clarendon Press.

ROSANVAllon, P. (2000) The New Social Question: Rethinking the Welfare State. Princeton, N.J.: Princeton University Press.

SENNETT, R. (2006) The Culture of the New Capitalism. New Haven \& London: Yale University Press.

\section{Case Cited}

R. (on the application of Reilly and Wilson) v. The Secretary of State for Work and Pensions [2012] EWHC 2292 (Admin); [2013] EWCA Civ 66; [2013] UKSC 68

\footnotetext{
${ }^{1}$ Beveridge's subsidiary methods for tackling Want were national assistance and voluntary insurance. The conditions of social insurance's success included the establishment of a comprehensive health care system (to keep the nation healthy and, thus, able to work) and the State's maintenance of employment. In other words, creating the conditions to facilitate work was one of the Report's core objectives.

${ }^{2}$ Freedland et al trace this reciprocal element of what they call active labour market policies to the 1920s. See Freedland et al 2007, Ch. 6.

${ }^{3}$ The current sanction regime can be found in sections 26 and 27 of the Welfare Reform Act 2012.

${ }^{4}$ Unless otherwise indicated, the sbwa scheme and the CAP will be referred to here as 'the schemes'.

${ }^{5}$ Contribution-based JSA is linked to the amount of National Insurance contributions an individual has paid in the last two tax years. Importantly, however, access to this benefit also depends on undertaking the work-related measures stipulated in the individual's claimant commitment. In other words, receipt
} 
of contribution-based JSA is not solely based on having made the requisite amount of national insurance contributions.

${ }^{6}$ In addition to claiming that the obligation to participate in the CAP violated Article 4, Wilson explained that the work he had been given to do bore no resemblance to his specific needs and to what was preventing him from entering the job market. Similar comments by others undertaking workfare schemes can be found in a recent report commissioned by the UK Government's Department of Work and Pensions: DWP 2014.

${ }^{7}$ For evidence of the unstable, low-paid, poor quality jobs that workfare participants tend to up in, see for example: Carpenter, Freda and Speeden 2007; and, Griggs and Evans 2010.

${ }^{8}$ In Roman Law, the term obligatio denoted a tie or bond between two parties - the creditor and the debtor - 'by which one party was bound, and the other entitled, to some act or forbearance ...' (Nicholas 1962, p. 158). 